\title{
Extracorporeal Shockwave Therapy in Cardiology: Current Status and Future Perspectives
}

\author{
AKM Monwarul Islam, AAS Majumder \\ Department opf Cardiology, NICVD, Dhaka.
}

Keywords: Shockwave, angiogenesis, angina.

\begin{abstract}
:
Management of end-stage coronary artery disease is often hopeless because of lack of evidence-based, uniformly effective, safe, and inexpensive treatment options. Gene- or stem-cell-based therapies are not yet ready for routine clinical use, and heart transplantation is seriously limited by the scarcity of organs. In this regard, extracorporeal shockwave therapy is emerging as a noninvasive means to treat refractory angina and heart failure. Shockwaves are a form of acoustic wave having very high amplitude, abrupt peaking and very short duration, capable of inducing neovascularization. A number of preclinical and clinical studies are in favour of its efficacy and safety. However, more robust evidence is needed before routine application is recommended. Larger, randomized, placebocontrolled trials will hopefully define its status in the armamentarium of mankind in the battle against the deadly disease in future.
\end{abstract}

(Cardiovasc. j. 2011; 4(1): 80-87)

\section{Introduction:}

As the survival of patients with primary coronary events continues to increase, the number of patients presenting with coronary artery disease unsuitable to further revascularization techniques and symptoms refractory to medical therapy also continues to rise. Side by side, As a consequence of the worldwide increase in life expectancy, and due to improvements in the treatment of heart failure in recent years, the proportion of patients that reach an advanced phase of the disease, socalled end stage, refractory or terminal heart failure, is steadily growing. ${ }^{1}$ Treatment options for these end-stage heart diseases are at present, limited to few modalities like stem-cell therapy and heart transplantation. Stem-cell therapy is promising but at present not in routine use. On the other hand, heart transplantation is seriously limited by the scarcity of donated organs. So, quest for newer, versatile and effective treatment modality is going on relentlessly. And to this effort, extra-corporeal shock-wave therapy may add to the armamentarium of mankind in the battle against end-stage heart disease.

\section{Basic concepts:}

Three types of acoustic waves are mainly used in the medical field, extracorporeal shock waves, pressure waves and ultrasound. Shock waves are three-dimensional acoustic waves characterized by high amplitudes and abrupt peaking of 35 to 120 MPa that propagates rapidly through a medium. ${ }^{2,3}$

They arise from sharp and violent disturbances generated from a lightning stroke, bomb blast, or other form of intense explosion. Many of the physical effects depend upon the energy involved, measured in millijoules (mJ). ${ }^{4}$ For medical use, shock waves are concentrated into small focal areas of 2 to $8 \mathrm{~mm}$ in diameter in order to optimize the therapeutic effects and to minimize the effects on other tissues. ${ }^{5}$

Shockwave energy per unit area= Energy flux density (EFD)

Energy flux density is expressed in millijoules (mJ).

Shockwave pressure is expressed in MegaPascal (MPa), or Bar.

$1 \mathrm{MPa}=10$ Bars.

Extracorporeal shockwave Therapy produces high energy shock waves and delivers them to the tissue via the surface of the skin. Shockwaves are

Address of Correspondance: Dr. AKM Monwarul Islam, Department of Cardiology, National Institute of Cardiovascular Diseases, Dhaka, Bangladesh. Email: drmonwarbd@yahoo.com 
generated by an electric storage capacitor with variable high voltage which is charged and subsequently rapidly discharged by electroacoustic transducers. ${ }^{6}$ The generators can work by means of electrohydraulic, electromagnetic or piezoelectric mechanisms. ${ }^{7}$ After generation, shockwaves are concentrated by means of focusing reflectors on the target site. Localization of the waves can be performed using echocardiography or fluoroscopy. In order to avoid induction of ventricular arrhythmias, they are applied to myocardium under ECG- $R$ wave gating.

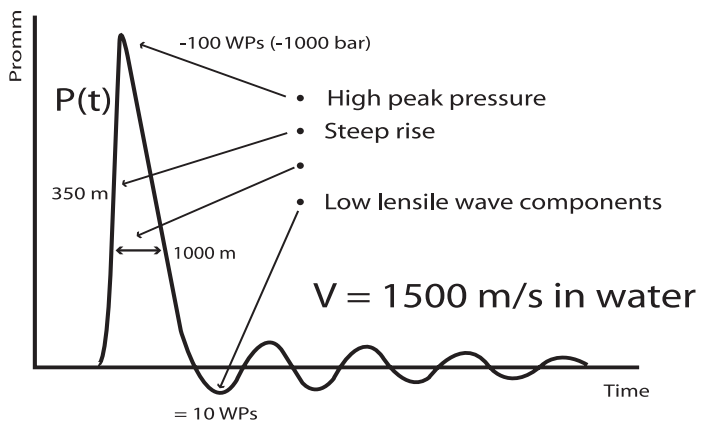

Fig.-1: Characteristics of shockwave. ${ }^{8}$

In spite of being sound waves, ultrasound and shockwaves are not same. Therapeutic ultrasound has lower level of energy $(<0.5 \mathrm{MPa})$, is diffuse, reflected by ribs and mainly acts by producing heat within the tissues. On the other hand, cardiac shockwaves have higher level of energy ( 10 MPa), are more focused, not reflected by ribs and mainly acts by producing mechanical effects. ${ }^{2,8}$

\section{Medical Application of Shockwave:}

Shockwaves are being used for more than two decades in urology, to breakdown renal stones (extra-corporeal shock-wave lithotripsy). It is also used to disintegrate gall stones. Orthopedic applications include treatment of planter fasciitis, epicondylitis, calcaneal spur, non-union, etc. 9,10 $^{9}$ For treatment of stones, high-energy (e.g. 900 Bars i.e. $90 \mathrm{MPa}$ ) shockwaves are used. On the other hand, low-energy, i.e. nearly one-tenth the energy of urological application (100 Bars i.e.10 MPa) is needed for cardiovascular conditions. ${ }^{8}$ Recently, shockwaves have been used to treat refractory skin ulcers $^{11-12}$, erectile dysfunction ${ }^{13}$ and chronic pelvic pain syndrome $\mathrm{e}^{14}$.

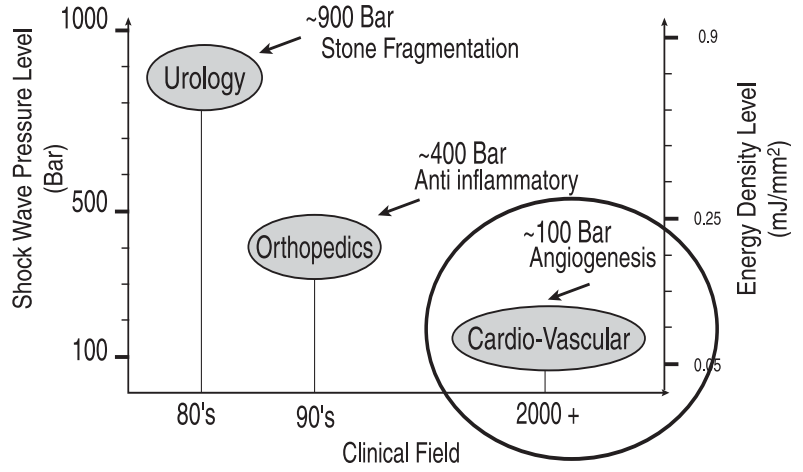

Fig.-2: Shockwaves used in different clinical fields. ${ }^{8}$

Mechanism of Cardiac Shockwave Therapy: The precise mechanism of action of shockwaves is currently unknown. Shockwaves produce on cells: the 'cavitation effect' i.e. a micrometer-sized violent collapse of bubbles inside and outside the cells, and shear stress on the cell membrane. ${ }^{15-18}$ this may result in induction of neovascularization ${ }^{18,19}$ via upregulation of endothelial nitric oxide synthesis, vascular endothelial growth factor (VEGF), its receptor (Fig-1), and proliferating cell antigen, and also recruitment of bone-marrow derived endothelial progenitor cells. ${ }^{19-22}$ Neovascularization improves myocardial perfusion, the result of which is increased stroke volume and cardiac output. However it is not yet known whether shockwaves affect cardiac myocyte regenerative potential. ${ }^{23}$

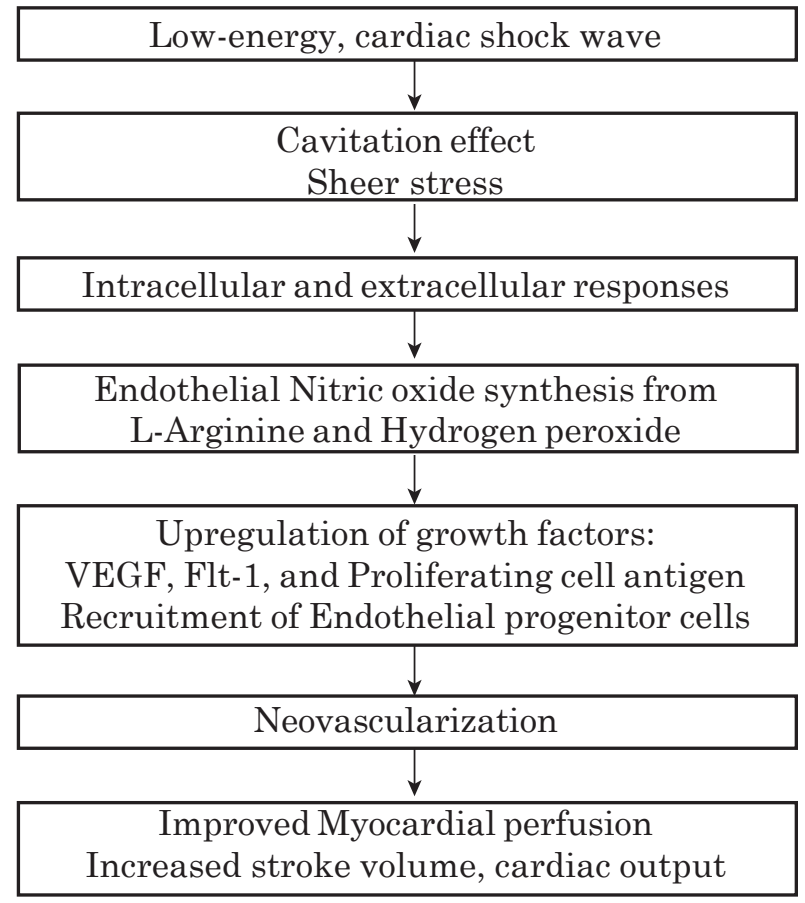

Fig.-3: Possible mechanism of action of cardiac shockwave therapy. 


\section{Methods of Application of Cardiac Shockwave Therapy:}

For clinical application, shockwaves are generated by electro-hydraulic effect. High voltage creates electric spark discharge. The water vaporizes and creates an explosion, generating high-energy shock-waves. Now the shockwaves are delivered non-invasively to the affected ischaemic area across the skin. Echocardiography is used to locate the area of interest, and to map the exact position and extent of ischaemic zone. Shockwaves are then delivered via the anatomical acoustic window to the treatment area under ECG-R wave gating to avoid ventricular arrhythmias. Several treatment sessions are required.

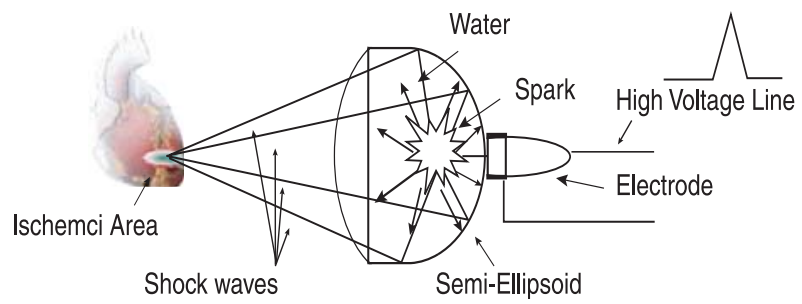

Fig.-4: Generation of shockwaves by electrohydraulic effect.

High voltage creates electric spark discharge; water vaporizes and creates an explosion, generating highenergy shock-waves which are delivered noninvasively to the affected ischaemic located by echocardiography under ECG-R wave gating.

There are currently no standardised guidelines for the use of shockwaves in cardiovascular conditions. A range of regimes with respect to the choice of machine, positioning and localisation of the patient, doses and treatment frequencies has been employed.

Extracorporeal shockwave therapy has been applied to patients symptomatic on minimal activity (CCS class III or IV) in spite of receiving maximally tolerated medical therapy with no possibility for percutaneous coronary intervention or bypass grafting on a recent angiogram.

Advantage of Cardiac Shockwave Therapy: A major advantage of extracorporeal cardiac shockwave therapy over PCI, CABG, and transmyocardial laser revascularization is that it is non-invasive and safe, without any known procedural complications or adverse effects. It can be done repeatedly even as outpatient procedure. Also, no surgery or anaesthesia is required. ${ }^{24}$
Studies Related to Cardiac Shockwave Therapy Shockwaves have chiefly been studied in coronary artery disease and heart failure. A number of studies have been carried out in animals with encouraging results. However, most of the studies are relatively small, and not well-designed.

\section{Refractory Angina Pectoris:}

Effects of low-energy shockwaves have been observed in both animals and humans. Nishida et al. observed significant up-regulation of mRNA expression of VEGF and its receptor Flt- 1 in cultured human umbilical vein endothelial cells treated with SW. Subsequently, a porcine model of chronic myocardial ischemia was made by placing an ameroid constrictor at the proximal segment of the left circumflex coronary artery, which gradually induced a total occlusion of the artery with sustained myocardial dysfunction but without myocardial infarction in 4 weeks. Thereafter, extracorporeal shockwave therapy to the ischemic myocardial region (200 shots/spot for 9 spots at $0.09 \mathrm{~mJ} / \mathrm{mm}^{2}$ ) was performed $(\mathrm{n}=8)$, which induced a complete recovery of $\operatorname{LVEF}(51 \pm 2 \%$ to $62 \pm 2 \%, p<0.01$ ), wall thickening fraction $(13 \pm 3 \%$ to $30 \pm 3 \%, p<0.01)$, and regional myocardial blood flow $(1.0 \pm 0.2$ to $1.4 \pm 0.3$ $\mathrm{ml} . \mathrm{min}^{-1} \cdot \mathrm{g}^{-1}, p<0.01$ ) of the ischemic region in 4 weeks, but not in control group. ${ }^{19}$

A human study was conducted by Fukumoto et al. which involved 9 patients with end-stage coronary artery disease with no indication of PCI or CABG. Extracorporeal shockwave therapy was applied to the patients $\left(200\right.$ shots/spot at $0.09 \mathrm{~mJ} / \mathrm{mm}^{2}$ for 20 40 spots, 3 times a week/series), and were followedup at 1, 3, 6, and 12 months after the therapy to examine the impact on myocardial ischemia. Canadian Cardiovascular Society (CCS) functional class score improved (from $2.7 \pm 0.2$ to $1.8 \pm 0.2, p<0.01$ ), nitroglycerin use decreased (from $5.4 \pm 2.5$ to $0.3 \pm 0.3$ / week, $p<0.05$ ), and myocardial perfusion improved in dipyridamole stress thallium scintigraphy (severity score, $25.2 \pm 7.2 \%$ improvement, $\mathrm{p}<0.05$; extent score, $23.3 \pm 9.0 \%$ improvement, $p=0.10$; washout rate, $20 \pm 3$ to $34 \pm 3, p<0.05){ }^{24}$

\section{Refractory Heart Failure:}

Studies have demonstrated symptomatic and objective improvement of cardiac function in heart failure. In a rodent model, left anterior descending artery was ligated to induce ischaemic heart failure (treatment group, $\mathrm{n}=60$, control group, $\mathrm{n}=60$ ). After 4 weeks, low-energy shock waves were applied over the epicardium in direct contact with the infarcted myocardium (300 impulses at $0.38 \mathrm{~mJ} / \mathrm{m}^{2}$ ). 
Histologic analysis revealed significant angiogenesis 6 weeks (treatment group: $8.2 \pm 3.7$ vs. control group: $2.9 \pm 1.9$ vessels/field, $p=0.016$ ) and 14 weeks (treatment group: $7.1 \pm 3.1$ vs. control group: $3.2 \pm 1.8$ vessels/field, $p=0.011$ ) after shock wave treatment. In the treatment group, ventricular function improved throughout the follow-up period after 6 weeks $(37.4 \% \pm 9 \%, p<0.001)$ and 14 weeks $(39.5 \% \pm 9 \%, \mathrm{p}<0.001)$, but not in the control group. Rat brain natriuretic peptide levels were lower and vascular endothelial growth factor, Fms-related tyrosine kinase 1, and placental growth factor levels were higher after 1, 2 and 7 days in the treatment group. ${ }^{25}$

In a human study by Vasyuk et al. 24 patients with ischemic heart failure and $\mathrm{LVEF}<40 \%$ received ECSW therapy in addition to their regular treatment. ECSW was performed in 9 sessions with 100 shocks per spot in viable segments, and the patients were evaluated at baseline and at 3 and 6 months. ESW significantly decreased NYHA class at 3 months (from $2.2 \pm 0.8$ to $1.7 \pm 0.7, p<0.01$ ) and 6 months $(1.7 \pm 0.7, p<0.01)$. Six-minute walk test improved at 3 months (from $414 \pm 141$ to $509 \pm 141$, $p<0.01$ ) and at 6 months (to $538 \pm 116, p<0.01$ ). CCS angina class decreased at 3 months (from 2.6 \pm 0.7 to $2.1 \pm 0.8, p<0.01$ ) and at 6 months (to $1.9 \pm 0.7$, $p<0.01)$. A significant increase in LVEF at rest at 3 and 6 months after shockwave therapy (from $32.2 \pm 6.0$ to $34.8 \pm 9.6$ and $37.7 \pm 9.5, p=0.03$, respectively) was noted. Summed rest score (from $23.9 \pm 8.1$ to $21.4 \pm 7.1, p=0.03)$ and stress score improvement (from $28.2 \pm 8.4$ to $24.6 \pm 6.4, p=0.04$ ) by SPECT was registered. ${ }^{26}$

\section{Acute Myocardial Infarction:}

Effect of shockwave therapy on LV remodeling has been observed in animal models of AMI by Uwatoku et al. ${ }^{27}$ and Ito et al. ${ }^{28}$ Uwatoku et al. created AMI by surgical excision of proximal left circumflex coronary artery $(n=20)$. In the early treatment protocol $(\mathrm{n}=5$, shockwaves were started 3 days after AMI), LVEF was higher ( $42 \pm 1$ vs. $32 \pm 1 \%, p<0.001$ ) and left ventricular end-diastolic volume (LVEDV) was smaller $(95 \pm 1$ vs. $99 \pm 2 \mathrm{ml}, p<0.05)$ in shockwave group compared with the control group $(\mathrm{n}=5)$. Furthermore, wall thickening fraction $(32 \pm 1$ vs. $28 \pm 1 \%, p<0.01$ ), regional myocardial blood flow $(1.7 \pm 0.2$ vs. $1.0 \pm 0.1 \mathrm{ml} / \mathrm{min} / \mathrm{g}, p<0.01)$, and number of capillaries in the border zone ( $1348 \pm 15$ vs. $938 \pm 34$ $\left.\mathrm{mm}^{2}, p<0.0001\right)$ were all significantly improved. By contrast, in the late treatment group $(n=5$, onset of therapy 4 weeks after AMI), no such beneficial effects of the shock wave therapy were noted. Recently, Ito et al. have demonstrated beneficial effects of SW therapy on LV remodeling in pigs. Pigs were subjected to a 90 -min ischemia followed by reperfusion using a balloon catheter and were randomly assigned to two groups with or without SW therapy to the ischemic border zone $(\mathrm{n}=15$ each). Four weeks after ischaemiareperfusion, compared with the control group, the shockwave group showed significantly ameliorated LV remodeling in terms of LV enlargement (131 \pm 9 vs. $100 \pm 7 \mathrm{ml})$, reduced LVEF ( $28 \pm 2$ vs. $36 \pm 3 \%$ ), and elevated LVEDP ( $11 \pm 2$ vs. $4 \pm 1 \mathrm{mmHg})($ all $p<0.05$, $\mathrm{n}=8$ each). The shockwave group also showed significantly increased regional myocardial blood flow $(-0.06 \pm 0.11$ vs. $0.36 \pm 0.13 \mathrm{ml} / \mathrm{min} / \mathrm{g}, p<0.05)$, capillary density $\left(1.233 \pm 31\right.$ vs. $1.560 \pm 60 / \mathrm{mm}^{2}$, $p<0.001$ ), and endothelial nitric oxide synthase activity $(0.24 \pm 0.03$ vs. $0.41 \pm 0.05, p<0.05)$ in the ischemic border zone compared with the control group ( $\mathrm{n}=7$ each).

\section{Peripheral Arterial Disease:}

Shockwaves have been applied for 3 weeks to hindlimb ischaemia in a rabbit model induced by the surgical excision of unilateral femoral artery. There were improvement of blood flow, blood pressure and capillary density in the affected limb receiving ESW, but not in the control group (Oi et al. 2008). ${ }^{29}$ Two clinical trials with 12 patients of Fontaine stage II of peripheral arterial disease have recently been reported by Serizawa et al. ${ }^{30}$ The patients were treated with SW session consisted of 200 shots in each 40 spots in the ischemic calf muscle at 0.004$0.054 \mathrm{~mJ} / \mathrm{mm}^{2}$. In the first trial, 6 patients with arteriosclerosis obliterans were treated with SW therapy 3 times per week in the first (day 1, 3, 5) and fifth weeks (day 29,31,33). The maximum walking distance at 4 and 8 weeks increased from baseline ( 0 week), but gradually decreased after 12 weeks. In the second trial, another 6 patients were treated (5 with arteriosclerosis obliterans and one with Buerger's disease) with shockwave therapy 3 times per week for 3 consecutive weeks. In this second trial, maximum walking distance significantly increased at 4 weeks $(166 \pm 6 \%$ from baseline, $p=0.04)$, and the beneficial effect of shockwave therapy sustained at 8 weeks $(153 \pm 5 \%$ from baseline, $p=0.03)$ and 12 weeks $(163 \pm 6 \%$ from baseline, $p=0.02)$ and 24 weeks $(156 \pm 12 \%$ from baseline, $p=0.0 \mathrm{X})$. No procedural complications or adverse effects were noted. 
Table-I

Studies related to cardiac shockwave therapy.

\begin{tabular}{|c|c|c|c|c|c|c|}
\hline $\begin{array}{l}\text { Study/ } \\
\text { Author(s }\end{array}$ & Type & Sample size & Indication & Methods & Results & Comment \\
\hline $\begin{array}{l}\text { Nishida et } \\
\text { al. }{ }^{19}\end{array}$ & $\begin{array}{l}\text { Randomized } \\
\text {, case- } \\
\text { control } \\
\text { study, in } \\
\text { pigs }\end{array}$ & $\begin{array}{l}\mathrm{N}=16 ; \text { cases }=8, \\
\text { controls }=8\end{array}$ & $\begin{array}{l}\text { Chronic myocardial } \\
\text { ischaemia induced } \\
\text { by ameroid } \\
\text { constrictor in } \\
\text { proximal LCX } \\
\end{array}$ & $\begin{array}{l}200 \text { shots } / \text { spot for } 9 \\
\text { spots at } 0.09 \\
\mathrm{~mJ} / \mathrm{mm}^{2}\end{array}$ & $\begin{array}{l}\text { Improvement of } \\
\text { LVEF, wall } \\
\text { thickening and } \\
\text { regional MBF. }\end{array}$ & $\begin{array}{l}\text { No } \\
\text { complicati } \\
\text { ons } \\
\text { observed. }\end{array}$ \\
\hline $\begin{array}{l}\text { Fukumoto } \\
\text { et al. }{ }^{24}\end{array}$ & $\begin{array}{l}\text { Non- } \\
\text { randomized } \\
\text { study, in } \\
\text { human }\end{array}$ & $\begin{array}{l}\mathrm{N}=9 \text {; } \text { cases }=9, \text { no } \\
\text { control }\end{array}$ & $\begin{array}{l}\text { End-stage coronary } \\
\text { artery disease with } \\
\text { no indications for } \\
\text { PCI or CABG }\end{array}$ & $\begin{array}{l}200 \text { shots } / \mathrm{spot}^{\text {at }} \\
0.09 \mathrm{~mJ} / \mathrm{mm}^{2} \text { for } \\
20-40 \text { spots, } 3 \\
\text { times a week/series } \\
\text { for } 3 \text { series; follow } \\
\text { up for } 12 \text { months. }\end{array}$ & $\begin{array}{l}\text { Positive effects on } \\
\text { symptoms, } \\
\text { nitroglycerine use, } \\
\text { MBF by dipyridamole- } \\
\text { stress scintigraphy. }\end{array}$ & $\begin{array}{l}\text { No } \\
\text { complicati } \\
\text { ons } \\
\text { observed. }\end{array}$ \\
\hline $\begin{array}{l}\text { Zimpfer et } \\
\text { al. }{ }^{25}\end{array}$ & $\begin{array}{l}\text { Randomized } \\
\text {, case- } \\
\text { control } \\
\text { study, in } \\
\text { rodents }\end{array}$ & $\begin{array}{l}\text { Cases }=60, \\
\text { controls }=60, \\
\text { healthy } \\
\text { controls }=30 \text {. }\end{array}$ & $\begin{array}{l}\text { Ischaemic heart } \\
\text { failure was induced } \\
\text { by ligation of LAD. }\end{array}$ & $\begin{array}{l}\text { After } 4 \text { weeks of } \\
\text { ligation, SW was } \\
\text { applied directly } \\
\text { over infarcted } \\
\text { myocardium ( } 300 \\
\text { impulses at } 0.38 \\
\left.\mathrm{~mJ} / \mathrm{m}^{2}\right) \text {; followed-up } \\
\text { for } 14 \text { weeks. }\end{array}$ & $\begin{array}{l}\text { Significantly } \\
\text { increased } \\
\text { angiogenesis, } \\
\text { upregulation of } \\
\text { growth factors, and } \\
\text { decreased brain } \\
\text { natriuretic peptide } \\
\text { levels in cases, but not } \\
\text { in controls. }\end{array}$ & $\begin{array}{l}\text { No } \\
\text { complicati } \\
\text { ons } \\
\text { observed. }\end{array}$ \\
\hline $\begin{array}{l}\text { Vasyuk et } \\
\text { al. }{ }^{26}\end{array}$ & $\begin{array}{l}\text { Non- } \\
\text { randomized } \\
\text { study, in } \\
\text { human }\end{array}$ & $\begin{array}{l}\mathrm{N}=24 ; \text { cases }=24, \\
\text { no control }\end{array}$ & $\begin{array}{l}\text { Chronic ischaemic } \\
\text { heart failure with } \\
\text { LVEF } 40 \% \text {, no } \\
\text { indications for PCI } \\
\text { or CABG. }\end{array}$ & $\begin{array}{l}100 \text { shots } / \mathrm{spot}^{2} \text { at } \\
0.09 \mathrm{~mJ} / \mathrm{mm}^{2}, 3 \\
\text { times a week/series } \\
\text { for } 3 \text { series; follow } \\
\text { up for } 6 \text { months. }\end{array}$ & $\begin{array}{l}\text { Improvement of } \\
\text { symptoms, six-minute } \\
\text { walk test, MBF by } \\
\text { SPECT. }\end{array}$ & $\begin{array}{l}\text { No } \\
\text { complicati } \\
\text { ons } \\
\text { observed. }\end{array}$ \\
\hline $\begin{array}{l}\text { Uwatoku } \\
\text { et al. }{ }^{27}\end{array}$ & $\begin{array}{l}\text { Randomized } \\
\text {, case- } \\
\text { control } \\
\text { study, in pig }\end{array}$ & $\begin{array}{l}\mathrm{N}=20 \text {; early } \\
\text { treatment protocol } \\
\text { cases }=5, \text { late } \\
\text { treatment protocol } \\
\text { cases }=5, \\
\text { controls }=5 \text { in each } \\
\text { group. }\end{array}$ & $\begin{array}{l}\text { AMI created by } \\
\text { surgical excision of } \\
\text { LCX. }\end{array}$ & $\begin{array}{l}\text { Early treatment } \\
\text { protocol: SW } \\
\text { therapy started } 3 \\
\text { days after AMI; late } \\
\text { treatment protocol: } \\
\text { SW therapy started } \\
4 \text { weeks after AMI. }\end{array}$ & $\begin{array}{l}\text { Significantly } \uparrow \text { LVEF, } \\
\downarrow \text { LVEDV, } \uparrow \text { wall } \\
\text { thickening, } \text { 个regional } \\
\text { MBF, and } \uparrow \text { number of } \\
\text { capillaries in early } \\
\text { treatment group. In } \\
\text { late treatment group, } \\
\text { no beneficial effects. }\end{array}$ & \\
\hline Ito et al. ${ }^{28}$ & $\begin{array}{l}\text { Randomized } \\
\text {, case- } \\
\text { control } \\
\text { study, in pig }\end{array}$ & $\begin{array}{l}\mathrm{N}=30 ; \text { cases }=15 \\
\text { controls }=15\end{array}$ & $\begin{array}{l}\text { AMI induced by } \\
\text { inflation of a } \\
\text { balloon catheter } \\
\text { followed by } \\
\text { reperfusion by } \\
\text { deflating the } \\
\text { balloon. }\end{array}$ & $\begin{array}{l}200 \text { shots/spot at } \\
0.09 \mathrm{~mJ} / \mathrm{mm}^{2} \text { for } 9 \\
\text { spots/animal, } 3 \\
\text { times in first } \\
\text { week/series; follow } \\
\text { up for } 1 \text { month. }\end{array}$ & $\begin{array}{l}\text { Significant positive } \\
\text { effects on LV } \\
\text { remodeling in terms of } \\
\text { LVIDD, LVEF and } \\
\text { LVEDP. Significantly } \\
\uparrow M B F \text {, capillary } \\
\text { density and eNO } \\
\text { synthase activity. }\end{array}$ & \\
\hline Oi et al. ${ }^{29}$ & $\begin{array}{l}\text { Randomize, } \\
\text { case-control } \\
\text { study, in } \\
\text { rabbits. }\end{array}$ & $\begin{array}{l}\mathrm{N}=18 ; \text { cases }=15, \\
\text { controls }=15\end{array}$ & $\begin{array}{l}\text { Surgical excision of } \\
\text { unilateral femoral } \\
\text { artery. }\end{array}$ & $\begin{array}{l}200 \text { shots } / \mathrm{spot}^{2} \text { t } \\
0.09 \mathrm{~mJ} / \mathrm{mm}^{2} \text { for } 30 \\
\text { spots, } 3 \text { times in } \\
\text { first week for } 3 \\
\text { weeks; follow up for } \\
1 \text { month. }\end{array}$ & $\begin{array}{l}\uparrow \text { blood flow, blood } \\
\text { pressure and capillary } \\
\text { density in the affected } \\
\text { limb. }\end{array}$ & \\
\hline $\begin{array}{l}\text { Serizawa } \\
\text { et al. }{ }^{30}\end{array}$ & $\begin{array}{l}2 \text { clinical } \\
\text { trials with } \\
12 \text { patients } \\
\text { in Fontaine } \\
\text { stage II. }\end{array}$ & $\begin{array}{l}\mathrm{N}=12 ; \text { First trial }= \\
6 \text { patients, Second } \\
\text { trial= } 6 \text { patients. }\end{array}$ & $\begin{array}{l}\text { Fontaine stage II of } \\
\text { peripheral arterial } \\
\text { disease. }\end{array}$ & $\begin{array}{l}200 \text { shots in } 40 \\
\text { spots at } 0.004- \\
0.054 \mathrm{~mJ} / \mathrm{mm}^{2} \text {. } \\
\text { First trial: } 3 \text { times/ } \\
\text { wk in week } 1 \& 5 \text {. } \\
\text { Second trial: } 3 \\
\text { times/wk for } 3 \\
\text { consecutive weeks. }\end{array}$ & $\begin{array}{l}\text { First trial: MWD at } 4 \\
\text { and } 8 \text { weeks } \\
\text { increased, but } \\
\text { gradually decreased } \\
\text { after } 12 \text { weeks. } \\
\text { Second trial: MWD } \\
\text { significantly increased } \\
\text { at } 4 \text { weeks. }\end{array}$ & $\begin{array}{l}\text { No } \\
\text { complicati } \\
\text { ons } \\
\text { observed. }\end{array}$ \\
\hline
\end{tabular}


Limitations of Cardiac Shockwave Therapy: The passage of shock waves to their target can result in damage to tissues. This may result in localized bleeding ${ }^{31,32}$, and damage to lung parenchyma $^{33}$. Higher energy pulses, $0.5 \mathrm{~mJ} / \mathrm{mm}^{2}$ or more, can facilitate free radical formation and cause ultrastructural changes in cytoplasm and mitochondria. ${ }^{34-37}$ Development of cardiac arrhythmias is another possibility. The pressure threshold for this appears to be in the range of 1 to $10 \mathrm{MPa} \cdot{ }^{38,39}$ However, most of these complications were not observed with low-energy shock waves used in cardiovascular arena.

\section{Current Status of Cardiac Shockwave Therapy:}

From the available data, extracorporeal cardiac shock-wave therapy appears to have some role in managing end-stage cardiac diseases, specially where standard revascularization procedures are not indicated. However, this modality of treatment has not been recommended for cardiac disorders by the prestigious regulatory authorities around the world, including Food and Drug Administration (FDA) of USA, Medicines and Healthcare products Regulatory Agency (MHRA) of UK, European Medicines Agency (EMA) of European Union and Therapeutic Goods Administration (TGA) of Australia. Standard treatment guidelines on coronary artery disease and heart failure have not yet addressed this issue. At present, a number of clinical trials are going on to determine the efficacy, as well as, the safety of cardiac shock wave therapy in refractory angina ${ }^{40-43}$ and advanced heart failure $^{44}$. However, these studies are relatively small.

\section{Future Directions:}

Extracorporeal cardiac shock-wave therapy is a new, non-invasive treatment modality for a number of cardiovascular disorders, including refractory angina and end-stage heart failure, where other standard therapies can not be applied. Its indications are rapidly expanding. Among others, peripheral vascular disease and impotence are the emerging applications. It can probably be used as a hybrid procedure in combination with existing revascularization strategies i.e. PCI and CABG, as well as, with other emerging modalities like gene or stem-cell therapy. However, its efficacy and safety should be ascertained by larger, multi-centric, placebo-controlled clinical trials. The indications and contraindications should more precisely be defined. Standard guidelines for the treatment of coronary artery disease and heart failure should address this newer modality, before routine applications. Otherwise, chances of its inappropriate and potentially harmful use remain.

\section{Conclusion:}

Extracorporeal cardiac shockwave therapy has brought about a ray of hope to a growing cohort of people of end-stage heart disease. It appears to be effective and safe for clinical use. However, further larger, multi-centric, placebo-controlled clinical trials are needed before recommendation of its routine clinical use. The indications and contraindications should more precisely be defined. Standard guidelines for the treatment of coronary artery disease and heart failure should address this newer modality, and define its exact role in management of heart diseases. Otherwise, inappropriate and potentially harmful use is of concern.

\section{Take-home Message:}

Extra-corporeal cardiac shock-wave therapy is a newer, non-invasive treatment modality.

Shockwaves are sound waves of very high amplitude and short duration.

Low-energy shockwaves are suitable for cardiovascular applications.

Present indications include refractory angina and heart failure, where PCI and CABG are not indicated.

The principal therapeutic benefit appears to derive from angiogenesis.

Uniform indications, contraindications, and treatment protocol are yet to be developed.

Not yet approved by regulatory authorities for treating cardiovascular conditions.

Potential future applications include as a hybrid procedure with gene or cell therapy.

Conflict of Interest - None.

\section{References:}

1. Friedrich EB, Böhm M. Management of end-stage heart failure. Heart 2007 93: 626-31.

2. Tsaklis PV. Presentation of acoustic waves propagation and their effects through human body tissues. Human Movement 2010, vol. 11 (1), 91-5. 
3. Speed CA. Extracorporeal shock-wave therapy in the management of chronic soft-tissue conditions. J Bone Joint Surg [Br] 2004;86-B:165-71.

4. Wess O, Ueberle F, Durhben RN, et al. Working group technical developments: Consensus report in high energy shock waves in medicine. In: Chaussy C, Eisenberger F, Jocham D, Wilbert D, eds. High energy shock waves in medicine. Thieme Stuttgart, 1997.

5. Auge BK, Preminger GM. Update on shock wave lithotripsy technology. Curr Opin Urol 2002;12:287-90.

6. Coleman AJ, Saunders JE. A review of the physical properties and biological effects of the high amplitude acoustic fields used in extracorporeal lithotripsy. Ultrasonics1993;31:75-89.

7. Coleman AJ, Saunders JE. A survey of acoustic output of commercial extracorporeal shock wave lithotripters. Ultrasound Med Biol 1989;15:213-27.

8. Medispec Ltd. Optimal cardiac neovascularization using the extra-corporeal shock-wave myocardial revascularization. www.medispec.com/pdf/ Cardiospec\%20 Brochure\%202008.pdf.

9. Birnbaum K, Wirtz DC, Siebert CH \& Heller KD. Use of extracorporeal shock-wave therapy (ESWT) in the treatment of non-unions. A review of literature. Arch Orthop Trauma Surg 2002; 122:324-30.

10. Wang CJ, Wang FS, Yang KD, Weng LH, Hsu CC, Huang CS \& Yang LC. Shock wave therapy induces neovascularization at the tendon-bone junction. A study in rabbits. J Orthop Res 2003;21:84-9.

11. Saggini R, Figus A, Troccola, Cocco V, Saggini A \& Scuderi N. Extracorporeal shock wave therapy for management of chronic ulcers in the lower extremities. Ultrasound Med Biol 2008;34:1261-71.

12. Moretti B, Notarnicola A, Maggio G, Moretti L, Pascone $\mathrm{M}$, Tafuri S \& Patella V. the management of neuropathic ulcers of the foot in diabetes by shock wave therapy. BMC Musculoskelet Disord 2009;10:54.

13. Vardi Y, Appel B, Jacob G, Massarwi O \& Gruenwald I. Can low-intensity extracorporeal shockwave therapy improve erectile function? A 6-month follow-up pilot study in patients with organic erectile dysfunction. Eur Urol 2010;58:243-8.

14. Zimmermann R, Cumpanas A, Miclea F \& Janetschek G. Extracorporeal shockwave therapy for the treatment of chronic pelvic pain syndrome in males: A randomized, double-blind, placebo-controlled study. Eur Urol 2009;03:043.

15. Apfel RE. Acoustic cavitation: A possible consequence of biomedical uses of ultrasound. $B r J$ Cancer 1982;45(suppl.):140-6.

16. Coleman AJ, Saunders JE, Crum LA, Dyson M. Acoustic cavitation generated by an extracorporeal lithotriper. Ultrasound Med Biol 1987;13:69-76.

17. Maisonhaute E, Prado C, White PC \& Compton RG. Surface acoustic cavitation understood via nanosecond electrochemistry. Part III: Sheer stress in ultrasonic. Ultrason Sonochem 2002;9:297-303.

18. Delius M, Draenert K, Draenert Y, Börner M. Effect of extracorporeal shock waves on bone: a review of shock wave experiments and the mechanism of action of shock wave action. In: Sibert W, Buch M, eds. Extracorporeal shock waves in orthopaedics. Berlin: Springer-Verlag, 91-108.

19. Nishida T, Shimokawa H, Oi K, Tatewaki H, Uwatoku $\mathrm{T}$, Abe K, et al. Extracorporeal cardiac shock wave therapy markedly ameliorates ischemia-induced myocardial dysfunction in pigs in vivo. Circulation 2004;110:3055-3061.

20. Gotte G, Amelio E, Russo S, Marlinghaus E, Musci G, Suzuki H. Short-time non-enzymatic nitric oxide synthesis from L-arginine and hydrogen peroxide induced by shock waves treatment. FEBS Lett 2002;520:153-5.

21. Mariotto S, Cavalieri E, Amelio E, Ciampa AR, de Prati AC, Marlinghaus E \& Suzuki H. Extracorporeal shock wave therapy in inflammatory diseases: Molecular mechanism that triggers anti-inflammatory action. Curr Med Chem 2009;16:2366-72.

22. Urbich C, Aicher A, Heeschen C, Dernbach E, Hofmann WK, Zeiher AM \& Dimmeler S. Soluble factors released by endothelial progenitor cells promote migration of endothelial cells and cardiac resident progenitor cells. $J$ Mol Cell Cardiol 2005;39:733-42.

23. Ito K, Fukumoto Y \& Shimokawa H. Extracorporeal shockwave therapy as a new and non-invasive angiogenic strategy. Tohoku J Exp Med 2009;219(1):19.

24. Fukumoto Y, Ito A, Uwatoku T, Matoba T, Kishi T, Tanaka H, Takeshita A, Sunagawa K \& Shimokawa H. Extracorporeal cardiac shock wave therapy ameliorates myocardial ischaemia in patients with severe coronary artery disease. Coron Artery Dis 2006;17:63-70.

25. Zimpfer D, Aharinejad S, Holfeld J, Thomas A, Dumfarth J, Rosenhek R, Czerny M, Schaden W, Gmeiner M, Wolner E \& Grimm M. Direct epicardial shock wave therapy improves ventricular function and induces angiogenesis in ischemic heart failure. $J$ Thorac Cardiovasc Surg 2009;137:963-70.

26. Vasyuk YA, Alla B. Hadzegova AB, Shkolnik EL, Kopeleva MV, Krikunova OV, Iouchtchouk EN, Aronova EM, Ivanova SV. Initial clinical experience with extracorporeal shock wave therapy in treatment of ischemic heart failure. Congest Heart Fail 2010;16(5):226-30.

27. Uwatoku T, Ito K, Abe K, Oi K, Hizume T, Sunagawa K \& Shimokawa H. Extracorporeal shock wave therapy improves left ventricular remodeling after acute myocardial infarction in pigs. Coron Artery Dis 2007;18:397-404.

28. Ito Y, Ito K, Shiroto T, Tsuburaya R, Yi GJ, Takeda M, Fukumoto Y, Yasuda S \& Shimokawa H. Cardiac shock 
wave therapy ameliorates left ventricular remodeling after myocardial ischaemia-reperfusion injury in pigs in vivo. Coron Artery Dis 2010;21(5):304-11.

29. Oi K, Fukumoto Y, Ito K, Uwatoku T, Abe K, Hizume T \& Shimokawa H. Extracorporeal shock wave therapy ameliorates hindlimb ischaemia in rabbits. Tohoku $J$ Exp Med 2008;214:151-8.

30. Serizawa F, Ito K, Sato A, Shimokawa H. Non-Invasive Extracorporeal Shock Wave Therapy Ameliorates Walking Ability in Patients with Peripheral Artery Disease and Intermittent Claudication. Circulation 2010;122:A14942.

31. Haake M, Boddeker IR, Decker T, et al. Side-effects of extracorporeal shock wave therapy (ESWT) in the treatment of tennis elbow. Arch Orthop Trauma Surg 2002;122:222-8.

32. Sistermann R, Katthagen BD. Complications, side effects and contraindications in the use of medium and high-energy extracorporeal shock waves in orthopaedics. Z Orthop Ihre Grenzgeb 1998;136:175-81.

33. Hartman C, Child SZ, Mayer R, Schenk E, Carstensen EL. Lung damage from exposure to the fields of an electrohydraulic lithotripter. Ultrasound Med Biol 1990;16:675.

34. Brummer F, Suhr D, Hulser D. Sensitivity of normal and malignant cells to shock waves. J Stone Dis 1992;4:243-8.

35. Brauner T, Brummer F, Hulser DF. Histopathology of shock wave treated tumour cell suspensions and multicell tumour spheroids. Ultrasound Med Biol 1989;15:451-60.

36. Russo P, Mies C, Huryk R, Heston WDW, Fair WR. Histopathologic and ultrastructural correlates of tumour growth suppression by high energy shock waves. J Urol 1987;137:338-41.

37. Kohri K, Iguchi M, Kurita T. Effect of high energy shock waves on tumour cells. Urol Res 1990; 18:101-5.

38. Dalecki D, Keller BB, Carstensen E, et al. Thresholds for premature ventricular contraction in frog hearts exposed to lithotripter fields. Ultrasound Med Biol 1991;17:341-6.

39. Delius M, Hoffmann E, Steinbeck G, Conzen P. Biological effects of shock waves: induction of arrhythmia in piglet hearts. Ultrasound Med Biol 1994;20:279-85.

40. Randomized, Placebo Controlled, Double Blind Clinical Trial Evaluating the Treatment of Patients With Refractory Angina Pectoris With Low Intensity Extracorporeal Shockwave Therapy Device. http:// www.clinicaltrials.gov/ct2/show/NCT01241968.

41. Randomized, Placebo Controlled, Double Blind Clinical Trial Evaluating the Treatment of Patients With Refractory Angina Pectoris With Low Intensity Extracorporeal Shockwave Therapy Device. http:// www.clinicaltrials.gov/ct2/show/NCT00662727.

42. Extracorporeal Shock Wave Therapy (ESWT) for the Treatment of Refractory Angina Pectoris. http:// www.clinicaltrials.gov/ct2/show/NCT00776568.

43. Shockwave Treatment for Advanced Angina in Maastricht (SWAAM): A Pilot Study. http:// www.clinicaltrials.gov/ct2/show/NCT01219218.

44. Extracorporeal Shockwave Myocardial Revascularization (ESMR). Therapy For The Treatment of Chronic Heart Failure. http://www.clinicaltrials.gov/ ct2/show/NCT01251185. 